\title{
Quantitative Assessment of Polycyclic Aromatic Hydrocarbons and Heavy Metals in Fish Roasted with Firewood, Waste Tyres and Polyethylene Materials
}

\author{
Ujowundu $\mathrm{CO}^{1 *}$, Ogbede $\mathrm{JU}^{1}$, Igwe $\mathrm{KO}^{1}$, Okwu GN ${ }^{1}$, Agha $\mathrm{NC}^{1}$ and Okechukwu $\mathrm{RI}^{2}$ \\ ${ }^{1}$ Department of Biochemistry, Federal University Technology Owerri, Nigeria \\ ${ }^{2}$ Department of Biology, Federal University Technology Owerri, Nigeria \\ *Corresponding author: Ujowundu CO, Department of Biochemistry, Federal University Technology Owerri, Nigeria, Tel: +2348036683491; E-mail: \\ ujowundu@yahoo.com
}

Rec date: Nov 05, 2014, Acc date: Dec 22, 2014, Pub date: Dec 24, 2014

Copyright: (c) 2014 Ujowundu CO, et al. This is an open-access article distributed under the terms of the Creative Commons Attribution License, which permits unrestricted use, distribution, and reproduction in any medium, provided the original author and source are credited.

\begin{abstract}
The bioaccumulation and biomagnification of PAHs along successive trophic levels is an important means of exposure to human and animal life. This study evaluated Polycyclic Aromatic Hydrocarbons (PAHs) and heavy metals in fresh fish and fish samples processed/ roasted with smoke/heat/flame generated from firewood, waste tyre and polyethylene materials. PAHs and heavy metals were determined with Gas chromatography with flame ionization detector (GC-FID) and Atomic Absorption Spectrophotometer (AAS) respectively. Significant differences $(P<0.05)$ were observed in the concentrations of PAHs and heavy metals in the heat-processed fish when compared to fresh fish. Appreciable amount of carcinogenic PAHs; benzo(a)pyrene, benz(a)anthracene and dibenz(a,h)anthracene benz(a)anthracene and dibenz(a,h)anthracene and heavy metals such as cadmium (Cd), zinc $(\mathrm{Zn})$ and lead $(\mathrm{Pb})$ were detected in processed/roasted fish samples.
\end{abstract}

Keywords: Carcinogenes; Mutagenes; PAHs; Heavy metals; Roasted fish

\section{Introduction}

Nigeria is one of the largest oil producing countries with enormous gas reserves and vast quantities of coal. There are also, large expanses of rain and mangrove forest with lush green vegetations. This implies abundant energy for domestic and industries uses. However, due to poor and outdated technology and/or poor investment on modern technology great percentage of gas reserves are flared as waste during crude oil exploration and exploitation by petroleum industries operating in Nigeria [1,2]. Also industrialization has led to the pollution of aquatic and terrestrial environment [3]. Most forest and fallowed farm lands serve as sink for pollutants generated by industries and households $[4,5]$. Despite these energy sources, most households and cottage industries cut corners by using and sourcing material which can be toxic as energy sources during food processing and preparation. Some of these materials include plastics, waste tyres, different package materials, waste engine oil, plastic foil etc. poor recycling culture and poor technological base have created opportunity for the use of waste tyres and plastics (polyethylene) materials as alternative energy sources.

Vehicle tyres (and items such as clothes fabrics, bridal veil, package paper, carpets, pies and ropes) are manufactured from nylon fibres. Nylon is a synthetic thermoplastic polymer made from molecules with a carboxylic $(-\mathrm{COOH})$ group and amino $\left(-\mathrm{NH}_{2}\right)$ group. Polyethylene (polythene) is a thermoplastic polymer consisting of long hydrocarbon chains. Most have a general formula, $\left(\mathrm{C}_{2} \mathrm{H}_{4}\right) \mathrm{nH}_{2}$. Polyethylene is mainly made from petroleum or natural gas. It is used primarily in making packagings such as plastic bags, plastic films, geomembranes, bottles etc.
At 392 OF polythene gives off gases which include ketones and aldehydes and at poor ventilation, carbon monoxide (CO) and carbon dioxide $\left(\mathrm{CO}_{2}\right)$ are produced. The combustion of these waste vehicle tyre materials releases polycyclic aromatic hydrocarbons (PAHs) and heavy metals. PAHs are a large group of over 100 different chemical compounds with 2 to 7 aromatic rings. Large quantities of PAHs are released into the environment by various human activities and they may have additive or synergistic effects with other environmental pollutants. They are formed by the incomplete combustion of organic material.

PAHs in the environment have become serious concern worldwide since the exposure to high concentrations has been linked to carcinogenic risk [6]. The routes of exposure to PAHs are from inhalation of ambient and indoor air, exhaust fumes or ingestion of food $[1,2,7,8]$. PAHs, notably benzo(a)pyrene $(\mathrm{BaP})$ have been reported to disturb the antioxidant defense system and it is also responsible for the induction of oxidative stress [9]. They compete with and displace essential mineral elements in the body, interfering with organ-system function, leading to disease conditions such as pulmonary edema, influenza, osteoporosis, kidney and central nervous dysfunction, thyroid dysfunction and liver failures [10]. The lack or poor knowledge of the toxicological implications on the use of these toxic materials is an important factor.

It is on this backdrop that we evaluated the amount of PAHs and some heavy metals in fish roasted with firewood, waste tyre and polythene materials as energy sources. This work is expected to educate and bring to the consciousness of Nigerians in particular and the world at large, the inherent toxicity in these unhealthy methods of food processing for human consumption. 
Citation: Ujowundu CO, Ogbede JU, Igwe KO, Okwu GN, Agha NC, et al. (2014) Quantitative Assessment of Polycyclic Aromatic Hydrocarbons and Heavy Metals in Fish Roasted with Firewood, Waste Tyres and Polyethylene Materials. Biochem Anal Biochem 4: 162. doi: 10.4172/2161-1009.1000162

Page 2 of 8

\section{Materials and Methods}

\section{Procurement and processing of fish samples}

Fresh fish samples used in this study were purchased from a market in Obinze Owerri, Imo State Nigeria. The fish samples were divided into four groups.

Group I, fresh fish not roasted (FF),

Group II, fish roasted with firewood (FRF),

Group III, fish roasted with firewood and waste tyre materials (FRT),

Group IV, fish roasted with firewood and waste polythene materials (FRP). The fish samples were roasted by exposing them to the heat, smoke and flame generated by these energy sources (firewood, waste tyre and polythene) for over four hours at high temperature.

\section{Determination of Polycyclic Aromatic Hydrocarbons (PAHs)}

The PAHs contents of samples were analyzed according to the method of American Petroleum Institute for analyzing petroleum hydrocarbons [11]. To extract the polycyclic aromatic hydrocarbons, $10 \mathrm{ml}$ of pentane was added to $2 \mathrm{~g}$ of each fish sample in a clean extraction vase. The set up was allowed to settle after thorough mixing. With the aid of filter paper fitted into Buchner funnels the mixture was carefully filtered into a clean extraction bottle. The extracts were concentrated to $2 \mathrm{ml}$ with rotary evaporator and then transferred for clean-up/separation in gas chromatograph.

A moderately packed glass wool of $1 \mathrm{~cm}$ was placed at the bottom of the $10 \mathrm{~mm}$ ID $\times 250 \mathrm{~mm}$ long chromatographic column. Then, a slurry $2 \mathrm{~g}$ activated silica gel in $10 \mathrm{ml}$ methylene chloride was placed into the chromatographic column. Afterwards, $0.5 \mathrm{~cm}$ of sodium sulphate was added to the top of the column and the column was rinsed with additional $10 \mathrm{ml}$ of methylene chloride. The column was pre- eluted using $20 \mathrm{ml}$ of pentane, and it was allowed to flow through the column for 2 minutes until the liquid in the column was just above the sulphate layer. This was immediately followed with a $1 \mathrm{ml}$ transfer of sample into the column. The stop clock of the column was opened and the eluent was collected in a $10 \mathrm{ml}$ graduated cylinder.

Just prior to exposure of the sodium sulphate layer to air, pentane was added to the column in 1-2 $\mathrm{ml}$ increments and then $8-10 \mathrm{ml}$ of the eluent was collected and labelled aliphatics.

The concentrated aliphatic fraction was transferred into labelled glass vials with rubber crimp caps for gas chromatographic analysis. A hypodermic syringe was used to inject $1 \mathrm{ml}$ of the concentrated sample through a rubber septum into the column. Separation occurred as the vapour constituent partitioned between the gas and liquid phases. The sample was automatically detected as it emerged from the column (at a constant flow rate) by the FID detector whose response depended on the composition of the vapour.

\section{Determination of heavy metals}

Preparation of ash: The heavy metal contents of the samples were determined using atomic absorption spectrophotometer according to the modified method of James [12]. The platinum dishes and their covers were cleaned, dried and ignited at $500^{\circ} \mathrm{C}$ for 30 minutes in a muffle furnace. The dishes and covers were cooled in a desiccator and weighed until a constant weight was obtained. Afterwards, $2 \mathrm{~g}$ of each fish sample was weighed into each dish. Ashing was carried out at $500^{\circ} \mathrm{C}$ with the dishes slightly opened to allow escape of gases (loss of chloride due to volcanisation tends to occur above $500^{\circ} \mathrm{C}$ ). Periodic checks were done to ascertain complete ashing (indicated by whitish remains in the platinum dishes).

\section{Calculations:}

Solution of the ash for metal analyses: Exactly $5 \mathrm{ml}$ of $10 \% \mathrm{HCl}$ solution was added to the recovered ash and this was warmed on a water bath to dissolve. The solution of ash was then aspirated on presentation to the Atomic Absorption Spectrophotometer (GBC Avanta Ver 2.02; linear LS through zero max error 0.0212, R2:1.0000) from wherein the concentrations of the individual metals were determined.

Statistical analysis: The data obtained were expressed as mean \pm standard deviation of triplicate determinations, and the test of statistical significance $(\mathrm{p}<0.05)$ amongst the groups was assessed using one way analysis of variance (ANOVA).

\section{Results}

The concentration of individual PAHs in fish samples are presented in Table 1. Differences were observed in the concentration of PAHs amongst fresh fish (Figure 1), fishes roasted with heat/smoke generated from wood (Figure 2), fish roasted with waste polyethylene (Figure 3) and waste tyre materials (Figure 4). The fish samples exposed to heat/smoke generated from waste tyre materials showed the highest concentration of both individual and total PAHs. This is followed by samples exposed to heat/smoke from polyethylene materials used to package water.

Aside Naphthalene, which was not detected in Fresh fish and Firewood roasted fish, the other non-carcinogenic PAHs were present in all the samples evaluated. The concentrations of all the noncarcinogenic PAHs in fresh fish were not significant when compared with other processed samples. The highest values of Naphthalene, Acenaphthylene, Fluorene, Anthracene and Fluoranthene were recorded in Fish roasted with polyethene. Whereas, fish roasted with waste tyre material showed the highest values for Acenaphthene, Phenanthrene and Pyrene, the concentrations of possibly carcinogenic PAHs in Fresh fish samples were negligible and not significant when compared to the roasted samples. Fish roasted with waste tyre materials presented the highest values for Chrysene, Benzo(b) fluoranthene and Benzo(k) fluoranthene, while Indeno (1,2,3cd)pyrene showed highest value in Fish roasted with polythene materials.

Similarly, the highest concentration of two probably carcinogenic PAHs: Benz(a)anthracene and Dibenz $(\mathrm{a}, \mathrm{h})$ anthracene were observed in Fish roasted with waste tyre materials and Fish roasted with polythene materials, respectively. Benzo(a)pyrene, a carcinogenic PAH to humans presented the lowest and highest concentrations in Fresh fish and Fish roasted with waste tyre materials, respectively. The summary concentration of PAHs in fish samples presented in Table 2, indicates that the total PAHs in fresh fish sample were negligible while highest total PAHs was observed in fish roasted with heat/smoke generated from waste tyre materials. Table 3 , shows the concentration of some heavy metals; cadmium, zinc and lead determined in the fish samples roasted with heat/smoke from waste tyres, firewood and fresh fish. A significant difference in lead concentration was observed in fish 
Citation: Ujowundu CO, Ogbede JU, Igwe KO, Okwu GN, Agha NC, et al. (2014) Quantitative Assessment of Polycyclic Aromatic Hydrocarbons and Heavy Metals in Fish Roasted with Firewood, Waste Tyres and Polyethylene Materials. Biochem Anal Biochem 4: 162. doi: 10.4172/2161-1009.1000162

Page 3 of 8

samples prepared from different sources of energy. Also, significant increase in the cadmium and lead concentrations respectively was observed.

\begin{tabular}{|c|c|c|c|c|}
\hline Compounds & $\begin{array}{l}\text { Fresh } \\
\times 10^{-5}\end{array}$ fish $\quad(\mathrm{mg} / \mathrm{kg})$ & $\begin{array}{l}\text { Firewood roasted fish }(\mathrm{mg} / \mathrm{kg}) \\
\times 10^{-5}\end{array}$ & $\begin{array}{l}\text { Tyre roasted fish }(\mathrm{mg} / \mathrm{kg}) \\
10^{-5}\end{array}$ & $\begin{array}{l}\text { Polyethylene roasted fish }(\mathrm{mg} / \mathrm{kg}) \\
\times 10^{-5}\end{array}$ \\
\hline Naphthalene ${ }^{(3)}$ & ND & ND & 7.14 & 9.85 \\
\hline Acenaphthylene ${ }^{(3)}$ & 0.44 & 6.18 & 7.47 & 10.57 \\
\hline Acenaphthene $e^{(3)}$ & 0.54 & 4.32 & 5.19 & 4.75 \\
\hline Fluorene $^{(3)}$ & 0.07 & 1.6 & 2.66 & 4.56 \\
\hline Phenanthrene ${ }^{(3)}$ & 0.06 & 1.83 & 3.79 & 3.04 \\
\hline Anthracene $^{(3)}$ & 0.11 & 3.78 & 5.83 & 6.97 \\
\hline Fluoranthene ${ }^{(3)}$ & 0.04 & 1.83 & 8.77 & 13.68 \\
\hline Pyrene $^{(3)}$ & 0.03 & 5.28 & 124 & 6.71 \\
\hline Benz(a)anthracene $e^{(2 A)}$ & 0.05 & 5.17 & 10.6 & 5.26 \\
\hline Chrysene ${ }^{(2 B)}$ & 0.09 & 2.52 & 16 & 3.6 \\
\hline Benzo(b) fluoranthene $(2 \mathrm{~B})$ & 252 & 5000 & 8240 & 7615 \\
\hline Benzo(k) fluoranthene ${ }^{(2 B)}$ & 0.07 & 0.543 & 14 & 1.99 \\
\hline Benzo(a)pyrene ${ }^{(1)}$ & 0.25 & 4.83 & 13.8 & 7.47 \\
\hline $\begin{array}{l}\text { Indeno } \\
\text { cd)pyrene }\end{array}$ & 46 & 924 & 3220 & 357.66 \\
\hline $\begin{array}{ll}\text { Dibenz } & (\mathrm{a}, \mathrm{h}) \\
\text { anthracene } & \end{array}$ & 0.06 & 7.51 & 11.4 & 13.47 \\
\hline Benzo(g,h,i)perylene ${ }^{(3)}$ & 0.43 & 16.9 & 7.1 & 25.69 \\
\hline \multicolumn{5}{|c|}{$1=$ carcinogenic polycyclic aromatic hydrocarbon to humans } \\
\hline \multicolumn{5}{|c|}{$2 \mathrm{~A}=$ probably carcinogenic polycyclic aromatic hydrocarbon } \\
\hline \multicolumn{5}{|c|}{$2 \mathrm{~B}=$ possibly carcinogenic polycyclic aromatic hydrocarbon } \\
\hline \multicolumn{5}{|c|}{ (3) =Non-carcinogenic polycyclic aromatic hydrocarbon } \\
\hline ND $=$ Not Detected & & & & \\
\hline
\end{tabular}

Table 1: PAHs concentration in fresh fish samples and fish samples roasted with (different fuel materials) firewood, tyre and polyethylene.

\begin{tabular}{|l|l|l|l|l|}
\hline Compounds & Fresh fish & Fish roasted with Firewood & Fish roasted with Tyre & Fish roasted with Polyethylene \\
\hline Polycyclic aromatic hydrocarbon $(\mathrm{mg} / \mathrm{kg})$ & 0.003 & 0.06 & 0.117 & 0.081 \\
\hline
\end{tabular}

Table 2: Total PAHs concentration in fresh fish and fish roasted with waste materials

\section{Discussion}

Polycyclic aromatic hydrocarbons, dioxins and polychlorinated biphenyls are industrial contaminants $[13,14]$ that accumulate in large quantities in river sediments [15], and through the food chain some are ingested by aquatic organisms. PAHs are important class of persistent organic pollutant produced mainly during incomplete combustion of coal, gasoline, diesel fuels, polyethylene, tyres as well as in smoked and grilled foods [16]. PAHs are resistant to degradation and are potent environmental pollutants with adverse health consequences. In-vivo and in-vitro studies indicates that a wide range of PAHs exhibit mutagenic, carcinogenic, teratogenic, genotoxic and immunotoxic potentials [17]. Results from varying strength of evident carcinogenesis in human and animal studies classified PAHs as carcinogenic (group 1), probably carcinogenic (group 2A), possibly carcinogenic (2B) and non-carcinogenic (3) [18].

In this study the values of PAHs in processed fish samples varied according to the fuel material used. The elevated PAHs in fish processed with firewood and waste (tyre or polyethylene) materials 
Citation: Ujowundu CO, Ogbede JU, Igwe KO, Okwu GN, Agha NC, et al. (2014) Quantitative Assessment of Polycyclic Aromatic Hydrocarbons and Heavy Metals in Fish Roasted with Firewood, Waste Tyres and Polyethylene Materials. Biochem Anal Biochem 4: 162. doi: 10.4172/2161-1009.1000162

Page 4 of 8

may be attributed to the incomplete combustion of these materials at the processing temperature. Roasting most often lead to contamination, formation and release of various PAHs. The high amount of PAHs in fish roasted with firewood and waste tyre materials is attributable to the tyre's hydrocarbon content and the quality of smoke generated during combustion. However, the negligible total PAHs in fresh fish samples indicates very low accumulation from river sources and its sediments [15]. This supports the assertion that roasting with these waste materials can generate and transfer toxicants on surfaces of food $[8,19]$.

Furthermore, the significantly high concentrations of carcinogenic PAHs; benzo(a)pyrene, benz(a)anthracene and dibenz(a,h)anthracene benz(a)anthracene and dibenz $(\mathrm{a}, \mathrm{h})$ anthracene, in roasted fish samples can be linked to the type of fuel material used. It is a fact that poorly controlled processing methods (consisting high temperature), results to incomplete combustion of fuel materials $[18,20,21]$ Also, the total PAHs in fish roasted with polyethylene (FRP) and tyre (FRT) which were above Turkey permissive limit $(0.01 \mathrm{mg} / \mathrm{kg})$, infers a possible public health risk with roasted food consumption [22]. However, benzo(a)pyrene, benz(a)anthracene and dibenz(a,h)anthracene concentrations were below the permissive limits of $10 \mu \mathrm{g} / \mathrm{kg}(0.01$ $\mathrm{mg} / \mathrm{kg}$ ) indicated by joint $\mathrm{FAO} / \mathrm{WHO}$ 1989. Also, benzo(a)pyrene concentrations in the processed samples were comparable to German acceptable limit of $1.0 \mu \mathrm{g} / \mathrm{kg}(0.001 \mathrm{mg} / \mathrm{kg})$. The use of tyre and polyethylene materials as fuel are good sources of naphthalene. This is indicated by their presence in FRP and FRT materials and also shows the tendency of processed food to bind this volatile compound. The absence of naphthalene in fresh fish (FF) and in fish roasted with firewood (FRF) corroborates this assertion.

\begin{tabular}{|l|l|l|l|}
\hline Samples & Cadmium $(\mathrm{mg} / \mathrm{kg})$ & Lead $(\mathrm{mg} / \mathrm{kg})$ & Zinc $(\mathrm{mg} / \mathrm{kg})$ \\
\hline Fresh fish & $0.001 \pm 0.00^{\mathrm{a}}$ & $0.001 \pm 00^{\mathrm{a}}$ & $16.207 \pm 0.90^{\mathrm{a}}$ \\
\hline Fish Roasted with Firewood & $0.610 \pm 0.09^{\mathrm{b}}$ & $1.477 \pm 0.20^{\mathrm{b}}$ & $20.133 \pm 0.49^{\mathrm{b}}$ \\
\hline Fish Roasted with Tyre & $0.733 \pm 0.08^{\mathrm{c}}$ & $1.617 \pm 0.15^{\mathrm{b}}$ & $20.717 \pm 0.35^{\mathrm{b}}$ \\
\hline Fish roasted with Polyethylene & $0.780 \pm 0.03^{\mathrm{c}}$ & $2.820 \pm 0.20^{\mathrm{c}}$ & $20.547 \pm 0.23^{\mathrm{b}}$ \\
\hline
\end{tabular}

Values in this table are mean \pm standard deviation of triplicate determinations. Values in each column with different superscripts are significantly different ( $\mathrm{p}<0.05$ ).

Table 3: Heavy metals concentration in fresh fish and fish roasted with waste materials.

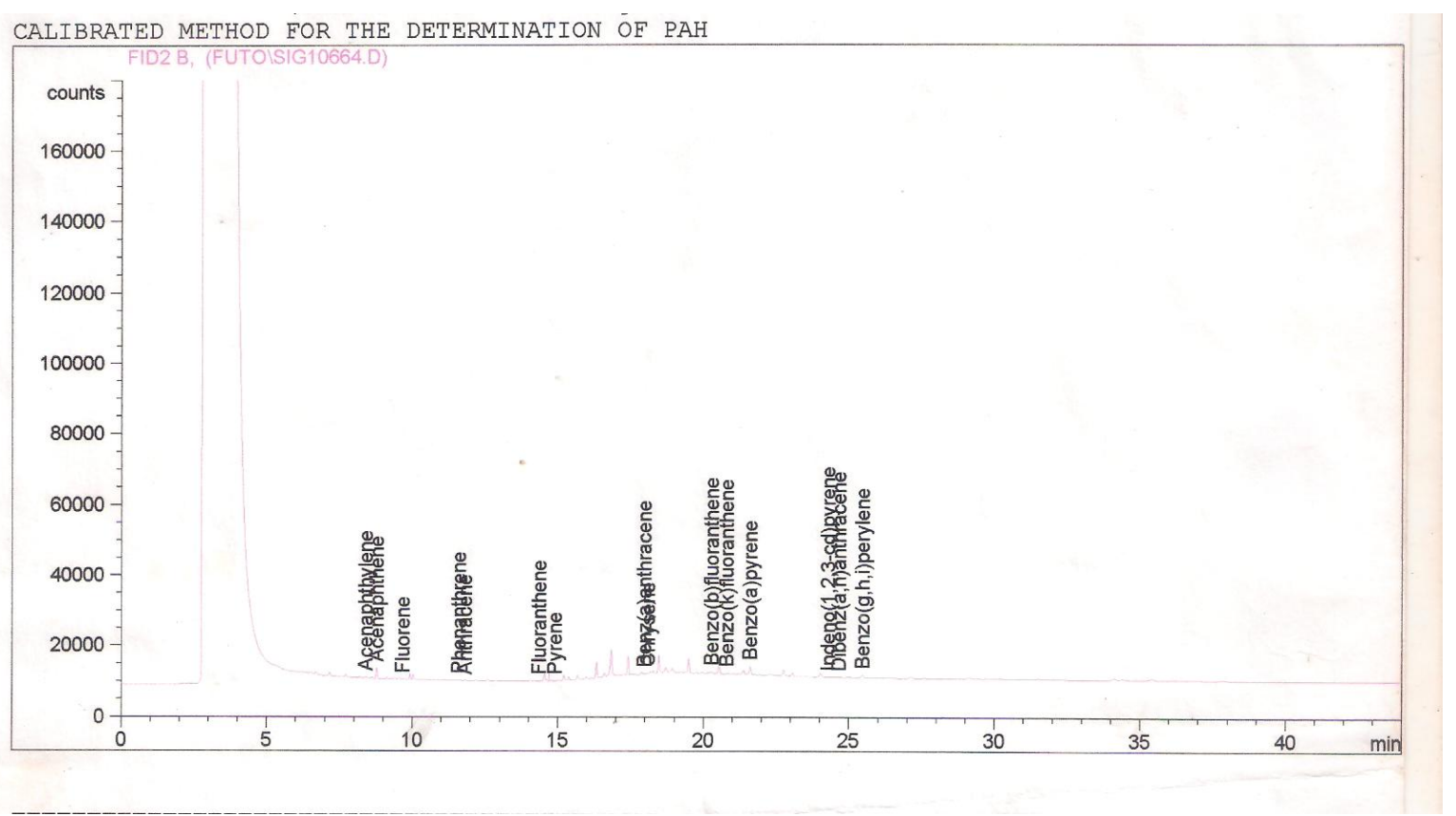

Figure 1: PAH in Fresh fish sample.

PAH molecules are metabolized by cytochrome P450 (CYPA1 and CYPA2) into a variety of oxygenated products [23], such as active diolepoxide, associated with high free radical production [24]. These diolepoxides covalently binds to DNA base pair, forming a stable depurinating adduct through electrophilic cabonium ions. This blocks polymerase replication activity and perturbs the double helix DNA structure [25]. These biochemical processes can disrupt proper DNA copying, increase DNA damage and reduce repair activities. Finally, initiating and promoting carcinogenesis [26]. These free radicals can attack polyunsaturated fatty acid abundant in membranes of cells in 
Citation: Ujowundu CO, Ogbede JU, Igwe KO, Okwu GN, Agha NC, et al. (2014) Quantitative Assessment of Polycyclic Aromatic Hydrocarbons and Heavy Metals in Fish Roasted with Firewood, Waste Tyres and Polyethylene Materials. Biochem Anal Biochem 4: 162. doi: 10.4172/2161-1009.1000162

Page 5 of 8

aerobic conditions to produce lipid peroxides, which induces oxidative damage of cells [27]. The presence and concentration of PAHs in the processed fish samples correlate positively with the assertion that roasting introduces carcinogenic compounds in food [28].

Our processed fish samples show varying concentrations of some heavy metals. These metals are known toxicants but under certain conditions and concentrations could be beneficial to some organisms. Metals such as zinc, copper, iron, and manganese are required in the body in small amount but can be toxic in large quantities [29].

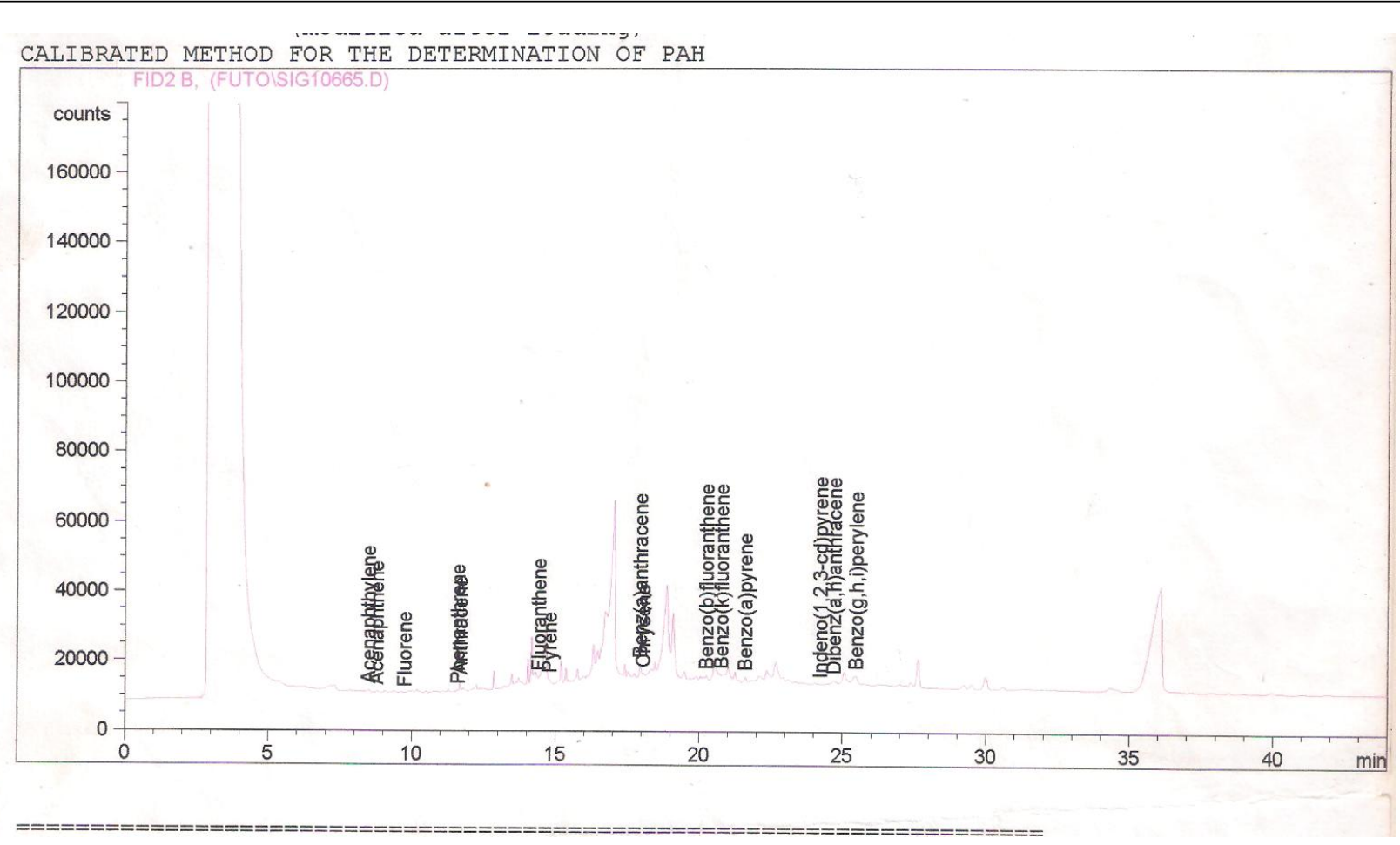

Figure 2: PAH in Fish roasted with Firewood only.

The observed concentration of cadmium was significantly $(\mathrm{P}<0.05)$ higher in FRP $>$ FRT $>$ FRF when compared to the fresh fish samples, which cadmium content can be said to be negligible [30]. The higher cadmium content in the processed fish samples could be linked to the roasting method and the fuel material constituent. In good accord with this assertion is the finding that, the concentrations of cadmium in FRP and FRT wastes were significantly higher than the permissive limits of $0.5 \mathrm{mg} / \mathrm{kg}$ set by European commission [30]. Dietary absorption of cadmium is favoured by deficiency of calcium, zinc, copper, iron and protein in diet. It stimulates the production of metalothionien (a zinc and other heavy metals binding protein), which strongly binds to it, forming a complex that initiates zinc and copper deficiency. This complex is transported to the kidneys where it can damage the filtering system. This damage causes sodium retention and excretion of essential proteins and sugars from the body [31]. However, our finding showed that the roasted fish had significantly higher amount of zinc, thereby downplaying the issue of zinc deficiency. Nevertheless, the concentrations of cadmium observed in the processed fish are of public health importance and because processed fish are regular/common ingredients in most Nigerian diets, chronic exposure which results into cadmium bioaccumulation is most likely.
The concentration of lead was negligible in FF but ranged from 1.57 $\mathrm{mg} / \mathrm{kg}$ in FRF to $2.83 \mathrm{mg} / \mathrm{kg}$ in FRP. Exposure to lead has a variety of health effect particularly in children and pregnant women. At the molecular level, lead mimics, displaces and inhibits the action of calcium transport in calcium-calmodulin dependent pathways thereby altering neurotransmission in brain and body [32]. It also inhibits haemoglobin biosynthesis by interfering with $\mathrm{D}$ - aminolevulinic acid dehydratase and ferrochelatase involved in heme formation resulting in production of zinc protoporphyrin causing haemolyticanaemia [33]. Lead concentrations are often hidden because it is deposited deep into bone marrows and bioaccumulates overtime. It interferes with DNA transcription enzyme involved in synthesis of Vitamin D and impedes vitamin $\mathrm{D}$ conversion into its hormonal form $(1,25$ dihydroxylvitamin $\mathrm{D}$ ), thereby impairing cell growth, teeth and bone development [34]. Lead alters collagen synthesis and blood vessel permeability. It can also trigger the excessive production of inflammatory proteins which is harmful to immune system development. Oxidative stress produced from lead toxicity suppresses antioxidant activity. Other systems affected are; renal, gastrointestinal and cardiovascular systems [35]. 
Citation: Ujowundu CO, Ogbede JU, Igwe KO, Okwu GN, Agha NC, et al. (2014) Quantitative Assessment of Polycyclic Aromatic Hydrocarbons and Heavy Metals in Fish Roasted with Firewood, Waste Tyres and Polyethylene Materials. Biochem Anal Biochem 4: 162. doi: 10.4172/2161-1009.1000162

Page 6 of 8

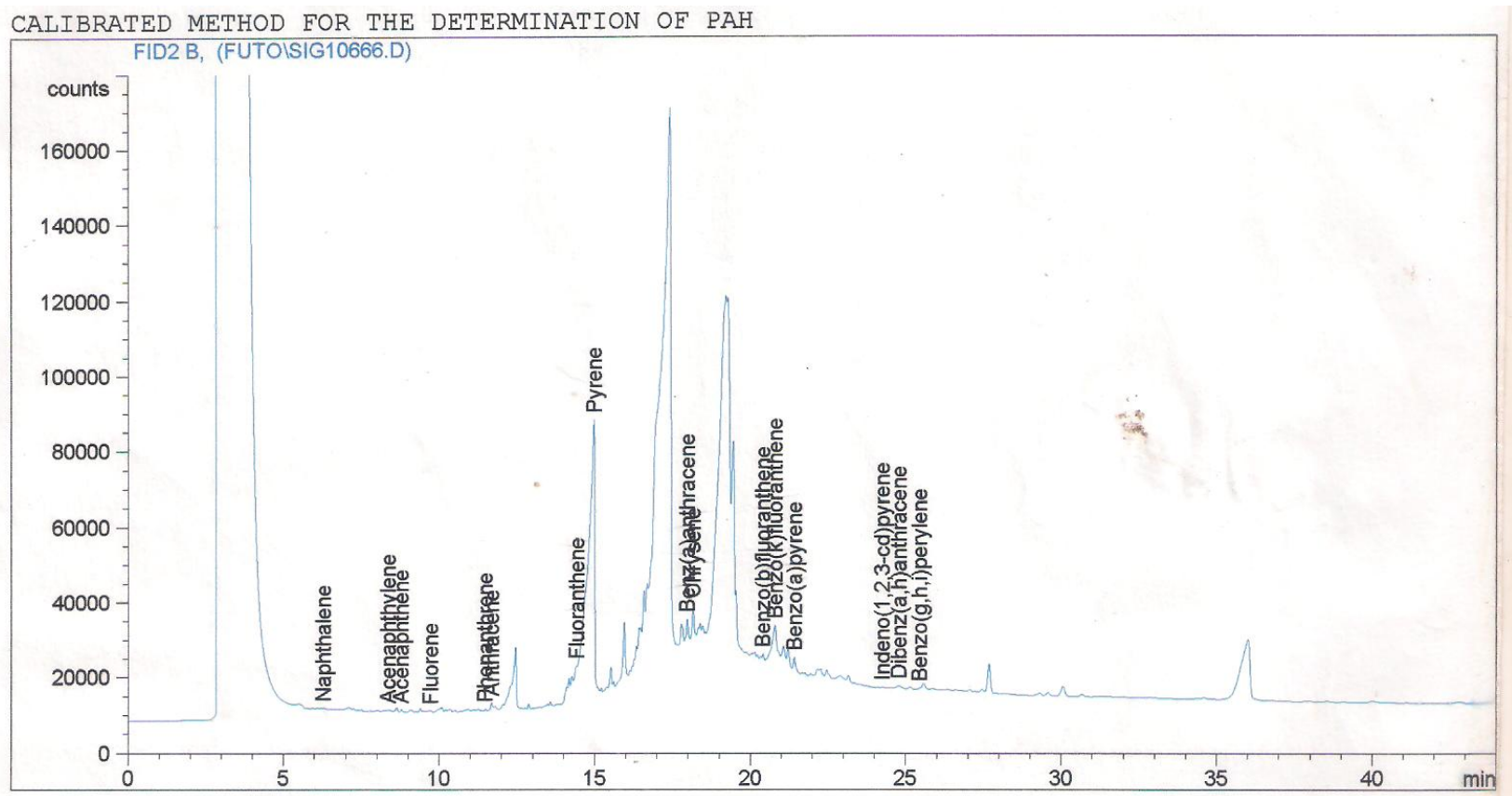

Futarnat Ctandard Dannrt

Figure 3: PAH in Fish roasted with waste tyre material.

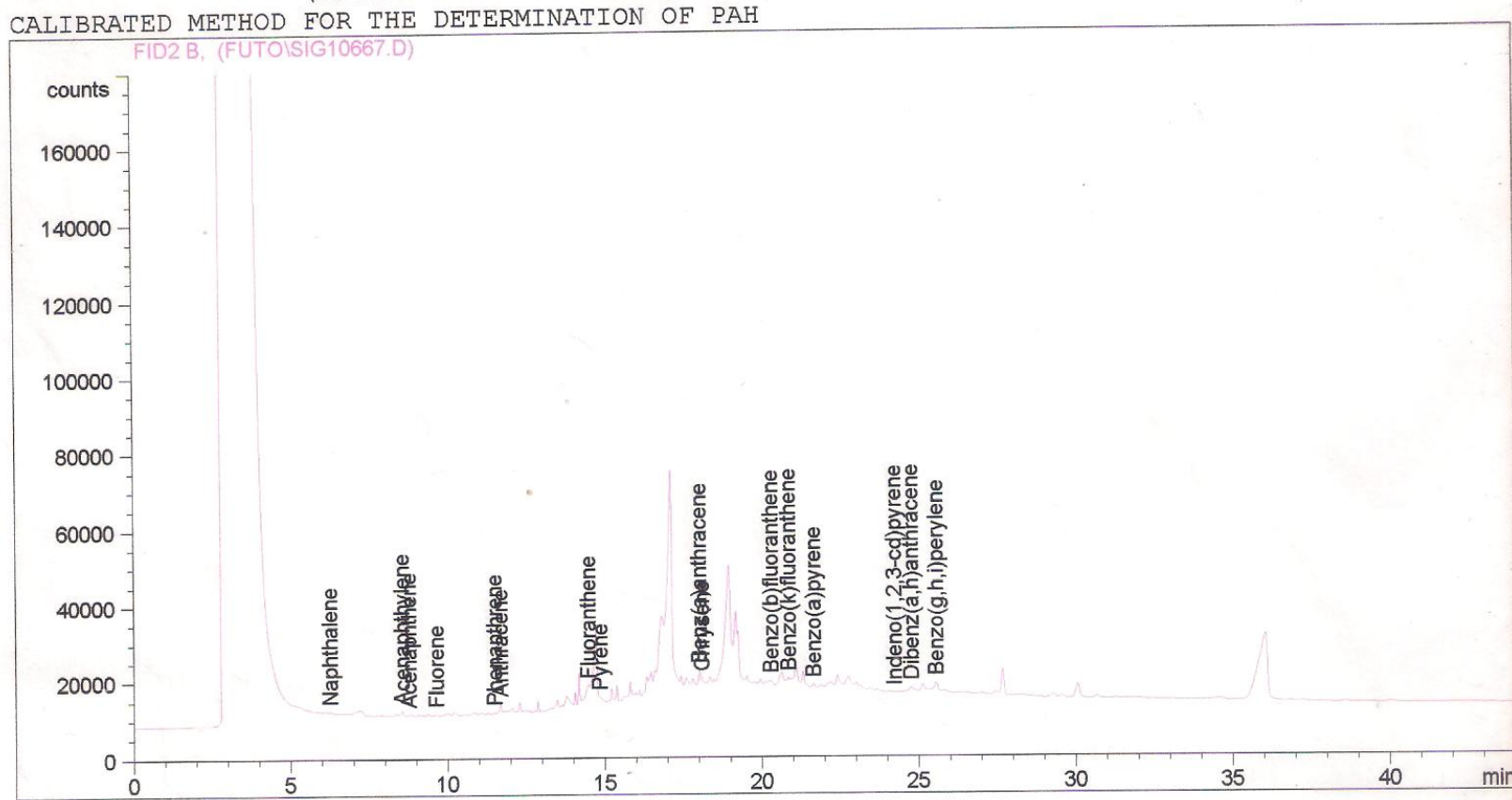

Figure 4: PAH in Fish roasted with waste Polyethylene material. 
Citation: Ujowundu CO, Ogbede JU, Igwe KO, Okwu GN, Agha NC, et al. (2014) Quantitative Assessment of Polycyclic Aromatic Hydrocarbons and Heavy Metals in Fish Roasted with Firewood, Waste Tyres and Polyethylene Materials. Biochem Anal Biochem 4: 162. doi: 10.4172/2161-1009.1000162

Page 7 of 8

The concentrations of zinc in fish samples roasted with firewood, polyethene and tyre materials were significantly higher compared to fresh fish samples. However, these zinc concentrations are below permissible limits of $150 \mathrm{mg} / \mathrm{kg}$ set by European commission [30]. Zinc is naturally occurring in sea foods and is known to play important roles in biochemical reactions at low concentrations [36]. Like magnesium, zinc serves as a co-factor to a number of critical enzymes. It is essential for immune function, healthy skin, protein and DNA synthesis and sensory organs [37].

\section{Conclusion}

These results are in agreement with the findings that methods of food preparation increase heavy metals and PAH concentrations $[8,38]$. However, the contamination of foods from these fuels materials added in the course of roasting food to generate heat and smoke is of great public health importance. Individuals and authorities at the local, State and Federal level should co-operate to expose this unhealthy practice and devise strategies to eliminate it.

\section{References}

1. Ujowundu CO, Nwaogu LA, Ujowundu FN, Belonwu DC (2013) Effect of Gas Flaring on the Phytochemical and Nutritional Composition of Treculia africana and Vigna subterranean. British Biotechnology Journal 3: 293-304

2. Ujowundu CO, Nwaogu LA, Igwe KO, Ujowundu FN, Belonwu DC (2013) Evaluation of the Impact of Oil and Gas Pollutants on the Chemical Composition of Abelmoschus esculentus Moench and Pterocarpus mildbraedii Harms. Journal of Research in Biology 3:8611-8869

3. Shore RF, Douben PE (1994) Predicting ecotoxicological impacts of environmental contaminants on terrestrial small mammals. Rev Environ Contam Toxicol 134: 49-89.

4. Akpofure EA, Efere ML, Auawei P (2000) Integrated Grassroot Post Impact Assessment of Acute Damaging Effects of Continuous Oil Spills in the Niger Delta. January 1998 - January 2000. The Adverse Effect of Crude Oil Spils in the Niger Delta.

5. Gbadebo AM, Taiwo AM, Ola OB (2009) Effect of crude oil and spent oil on Clarias garipinus ; A typical marine fish. American Journal of Environmental Sciences $5: 753-758$.

6. Mahadevan B, Marston CP, Dashwood WM, Li Y, Pereira C et al. (2005) Effect of a standardized complex mixture derived from coal tar on the metabolic activation of carcinogenic polycyclic aromatic hydrocarbons in human cells in culture. Chem Res Toxicol 18: 224-231.

7. John H (2002) Heavy metal 'a meaningless term (IUPAC technical report). Pure and Applied Chemistry. 74:793-807.

8. Ujowundu CO, Ihekweazu KL, Alisi CS, Ujowundu FN, Igwe CU (2014) Procarcinogens Polycyclic Aromatic-Hydrocarbons and Heavy Metal Content in Some Locally Processed Foods in South Eastern Nigeria. British J. Applied Science and Tech., 4: 249-260.

9. Saunders CR, Das SK, Ramesh A, Shockley DC, Mukherjee S (2006) Benzo(a)pyrene-induced acute neurotoxicity in the F-344 rat: role of oxidative stress. J Appl Toxicol 26: 427-438.

10. Ujowundu CO, Okoye HN, Nwaoguikpe RN, Belonwu DC, Igwe KO, Ujowundu FN (2014) Hepatoprotective Effects of Crude Extracts of Tomato and Onion in Rats Exposed to Locally Processed Beef. International Journal of Biochemistry Research \& Review 4: 193-203

11. API American Petroleum Institute (1994) Interlaboratory study of three methods for analyzing petroleum hydrocarbons in soils, diesel-range organics (DRO), and gasoline-range organics (GRO). Petroleum Hydrocarbon (PHC)

12. James CS (1995) Analytical chemistry of foods. Chapman and hall: New York 52-55.
13. White RD, Shea D, Stegeman JJ (1997) Metabolism of the aryl hydrocarbon receptor agonist 3,3',4,4'-tetrachlorobiphenyl by the marine fish scup (Stenotomus chrysops) in vivo and in vitro. Drug Metab Dispos 25: 564-572.

14. van der Oost R, Beyer J, Vermeulen NP (2003) Fish bioaccumulation and biomarkers in environmental risk assessment: a review. Environ Toxicol Pharmacol 13: 57-149.

15. Malins DC, McCain BB, Brown DW, Chan SL, Myers MS et al. (1984) Chemical pollutants in sediments and diseases of bottom-dwelling fish in Puget Sound, Washington. Environ. Sci. Technol 18: 705-713.

16. Goldman R, Shields PG (2003) Food mutagens. J Nutr 133 Suppl 3: 965S-973S.

17. US EPA, US Environmental Protection Agency (2000) Drinking Water Criteria for Polycyclic Aromatic Hydrocarbons (PAHs). Prepared by the Environmental Criteria and Assessment, Office, Office of Health and Environmental Assessment, Cincinnati, OH, for the Office of Water, Washington, DC. ECAO-CIN-D010

18. IARC (2010) IARC Monographs on the evaluation of carcinogenic risk to humans. International Agency for research on cancer. 92.

19. Martinez C, Fermandez C, and Simai G (2012) Searching ingredients polluted by polycyclic aromatic hydrocarbon in food due to pyrolytic sources. J Food chemistry 135: 2043-2051

20. Jahnke M (2001) Control of food safety hazard during smoked fish processing. J food sci 66:1104-1112.

21. Falcó G, Domingo JL, Llobet JM, Teixidó A, Casas C, et al. (2003) Polycyclic aromatic hydrocarbons in foods: human exposure through the diet in Catalonia, Spain. J Food Prot 66: 2325-2331.

22. Turkish food codex (2002) Communique on determining the maximum level of certain contaminant in food stuff. The official Gazette 23.09.2002/24885. Communication No: 2002/63.

23. Wu J, Ramesh A, Nayyar T, Hood DB (2003) Assessment of metabolites and AhR and CYP1A1 mRNA expression subsequent to prenatal exposure to inhaled benzo(a)pyrene. Int J Dev Neurosci 21:333-346.

24. Gelboin HV (1980) Benzo[alpha]pyrene metabolism, activation and carcinogenesis: role and regulation of mixed-function oxidases and related enzymes. Physiol Rev 60: 1107-1166.

25. Perera FP, Rauh V, Whyatt RM (2006) Effects of prenatal exposure to airborne polycyclic aromatic hydrocarbons on neurodevelopment in the first 3 years of life among inter-city children. Environ Health Perspect. 114:1287-1292.

26. Wania G (2006) Polycyclic aromatic hydrocarbons, Chemistry and Carcinogenicity. Cambridge University Press, Cambridge, UK. 11-87.

27. Stog K, Agarstad M (2004) Genotoxicity of heat processed food. Mutation Res. 574: 156-72.

28. Jägerstad M, Skog K (2005) Genotoxicity of heat-processed foods. Mutat Res 574: 158-175.

29. Abdul W (2011) The Environmental impact of Gold mines pollution by heavy metal. Journal of Central European Engineering. 2: 304-313.

30. E.C Commission Regulation (2006) Monitoring for Polycyclic aromatic hydrocarbon in smoked fish. J. Eur Union 1881: 43-45.

31. Nordberg GF (2010) Biomarkers of exposure, effects and susceptibility in humans and their application in studies of interactions among metals in China. Toxicol Lett 192: 45-49.

32. Quarterman J, Morrison E (1978) The effect of age on the absorption and excretion of lead. Environ Res 17: 78-83.

33. James HM, Hilburn ME, Blair JA (2003) Effects of meals and meal times on uptake of lead from the gastrointestinal tract in humans. Hum Toxicol 4: 401-407.

34. Flammagan P (1999) The relationship between iron and lead absorption in humans. Am j. clins 36: 823-39.

35. Mehans S (2006) Lead retention by lungs of lead exposed women. Am occup Hyg 9: 165-72.

36. Mocchegiani E, Romeo J, Malavolta M, Costarelli L, Giacconi R, et al. (2013) Zinc: dietary intake and impact of supplementation on immune function in elderly. Age (Dordr) 35: 839-860. 
Citation: Ujowundu CO, Ogbede JU, Igwe KO, Okwu GN, Agha NC, et al. (2014) Quantitative Assessment of Polycyclic Aromatic Hydrocarbons and Heavy Metals in Fish Roasted with Firewood, Waste Tyres and Polyethylene Materials. Biochem Anal Biochem 4: 162. doi: 10.4172/2161-1009.1000162

Page 8 of 8

37. Aliani M, Udenigwe CC, Girgih AT, Pownall TL, Bugera JL, et al. (2013) Zinc deficiency and taste perception in the elderly. Crit Rev Food Sci Nutr 53: 245-250.
38. Egbu A (2000) Constraints to Effective Pollution Control and Management in Nigeria. The Environmentalist. 20: 13-17. 